\title{
Editorial
}

\section{A importância de publicar}

O número de publicações é uma das medidas mais usadas para definir o nível académico e a qualidade do currículo de um médico. É, contudo, uma régua que não mede o verdadeiro valor clínico, na capacidade de fazer um diagnóstico brilhante ou da sua competência técnica, e muito menos mede o nível da sua dedicação profissional e a capacidade de criar uma relação empática com o doente. Portanto, publicar pode não ser muito importante para a maioria dos médicos, cuja missão principal é tratar pessoas, e que acabam por evoluir na sua carreira em resultado da experiência acumulada, senso clínico aperfeiçoado por vários anos de prática, reconhecimento e gratidão dos seus pacientes. Afinal, não é esse um dos aspectos mais belos da nossa arte?...

Porém, um médico com hábitos de publicação ganha crédito na sua área, é considerado uma referência pelos seus pares e acaba, inevitavelmente, por influenciar a prática dos demais. Isso acontece por várias razões. Em primeiro lugar, porque a publicação é o veículo preferencial de divulgação dos resultados de investigação original, que eventualmente terão impacto na prática clínica. É conhecido o adágio de que só o que é publicado é que existe. Ou seja, para que a nossa experiência tenha realmente impacto na comunidade médica, não basta aclamá-la, precisamos de a descrever detalhadamente, com métodos reprodutíveis e demostração da evidência de que essa actuação produz resultados. Não nos esqueçamos, também, que publicar é habitualmente o resultado final de um longo percurso de perseverança, partindo de uma hipótese ou pergunta de investigação, estruturação de um protocolo para a testar, registo dos seus resultados, transcrição destes para um artigo científico e finalmente propô-lo a publicação. O próprio exercício de escrita exige um enorme trabalho de pesquisa bibliográfica, condensando em escassos parágrafos as ideias fundamentais de dezenas ou até centenas de referências. Este processo, por vezes longo, permite ao autor manter-se actualizado com os estudos mais recentes, e ajuda-o mais eficazmente a organizar mentalmente os seus conhecimentos, através de repetidas sequências de pesquisa, leitura e escrita. Por consequência, é um processo com o potencial de nos tornar melhores médicos, traduzindo-se directamente na melhoria dos cuidados de saúde. Por outro lado, o autor desenvolve elevadas capacidades comunicativas. Uma das coisas que mais me impressiona nos especialistas que mais publicam é a clareza do seu discurso, a forma lúcida e informada com que conseguem transmitir ideias complexas. Tal como na conhecida frase, atribuída a Albert Einstein: "Se tu não consegues explicar algo de forma simples, tu não o compreendes suficientemente bem." Ora, um investigador sabe bem o que escreve, e um autor compreende melhor do que ninguém a sua investigação.

Poder-se-á dizer que publicar é também um dever, inscrito na nossa generosa missão de partilha de conhecimentos com os colegas. Existe uma certa admiração, quase "religiosa", para com os nossos 
mentores e, em certa medida, isso também se aplica a quem nos oferece a sua publicação. É esta prática que permite que o mais avançado estado da arte beneficie o maior número de doentes possível. Apesar da nobreza do acto, existem aspectos igualmente práticos que são decisivos na motivação de publicar. Reservei para a última parte deste texto uma visão pessoal sobre a importância que as publicações tiveram na minha curta carreira. Um propósito fundamental é na candidatura a um emprego. Continuo a considerar que o meu artigo mais importante foi o primeiro, por duas razões principais. Primeiro, pela aprendizagem e pelo desbloquear de uma série de anseios e dúvidas relativamente a esse processo. Em segundo, porque me abriu portas para um lugar na academia, como assistente convidado de uma escola médica que não me conhecia. No currículo do jovem candidato, recém-licenciado, constava um artigo publicado em revista indexada e com factor de impacto, de uma investigação realizada ainda em fase pré-graduada, numa área bem distinta daquela que vários meses mais tarde viria a abraçar como especialidade médica. Sei hoje que essa informação curricular foi preponderante no sucesso da minha candidatura, e reconheço a importância que a experiência da docência teve no meu desenvolvimento pessoal. Outro propósito prático da publicação é a obtenção de um grau. A publicação de artigos foi valorizada na classificação final do exame de especialidade, e será daqui a breves anos na progressão da carreira médica para o grau de consultor. Existe também um mínimo de artigos publicados para a conclusão dos estudos conducentes a grau académico, nomeadamente mestrado ou doutoramento. Mais tarde, na candidatura a financiamento para projectos de investigação, o histórico de publicações do investigador principal confere sempre uma vantagem competitiva.

Para um médico, independentemente do genuíno prazer que se retire em investigar e em ver o nosso trabalho publicado, existem ganhos objectivos para o autor, pela credibilidade que ganha e se traduz em maiores oportunidades para a sua carreira, ou seja simplesmente para patentear a nova descoberta que resultou da sua investigação. "Publish or perish" (publique ou pereça) ${ }^{1}$ é uma máxima bem conhecida no mundo académico e científico, associando a importância de publicar à própria existência, como se tratasse de um pensamento cartesiano, "publico, logo existo". A urgência em publicar acarreta simultaneamente alguns riscos, na prossecução de estudos sem verdadeiro interesse prático, produzindo publicações fúteis em revistas científicas de duvidosa qualidade, que hoje proliferam e, por vezes, afasta-nos perigosamente da nossa missão assistencial. O futuro certamente demonstrará que a importância de publicar deve estar aliada, e não se sobrepor, à dedicação clínica.

Helder Novais e Bastos

\section{REFERÊNCIAS}

1. Coolidge HJ, editor. United States: Books for Libraries; 1932. Archibald Cary Coolidge: Life and Letters; p. 308

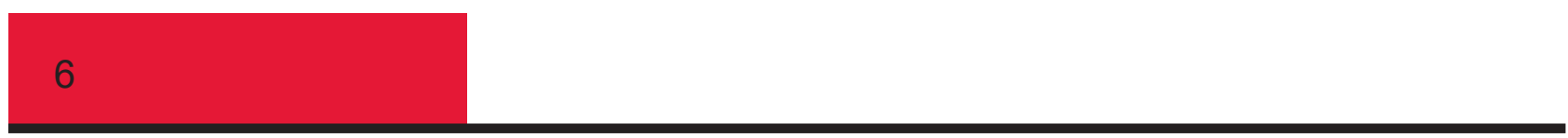

